\title{
Proteins in the uterine secretions of the cow
}

\author{
S. N. Dixon and R. A. Gibbons* \\ Agricultural Research Council, Institute for Research on Animal Diseases, Compton, Newbury, \\ Berkshire, RGI6 ONN, U.K.
}

\begin{abstract}
Summary. Cows of normal reproductive history were treated with progesterone for periods of 2-3 months. The uterine secretions yielded 5 major fractions of macromolecular components. Two of the fractions comprised serum proteins. In the other 3 fractions at least 9 non-serum proteins were observed, 7 in one fraction, but in only small amounts. Of the remaining 2 non-serum proteins one is an acid phosphatase recoverable in small amounts, and the other is lactoferrin and is the major non-serum protein present in the uterine secretions of progesterone-treated cows.
\end{abstract}

\section{Introduction}

The uterine secretion, constituting as it does the environment of the early embryo, is likely to be of importance in mammalian reproduction, particularly in ruminants in which the processes of implantation and placentation are relatively slow (Milton, Berry \& Butler, 1951; Greenstein, Murray \& Foley, 1958). The first clear confirmation of this importance stems from the embryo transplant work of Rowson \& Moor (1966) and Rowson, Lawson, Moor \& Baker (1972), who found a rather stringent requirement for synchrony between donor and recipient. This implies that the uterine environment is changing quite rapidly with time and furthermore that such changes in composition are vitally concerned with the survival of the embryo.

The information we have at present on the composition of the mammalian uterine secretion is extensive but somewhat superficial (man: Beier, Petry \& Kühnel, 1970; Wolf \& Mastroianni, 1975; Roberts, Parker \& Henderson, 1976a; rat: Kunitake, Nakamura, Wells \& Moyer, 1965; Perrine, 1967; Dupont-Mairesse \& Galand, 1975; Umpathysivam \& Breed, 1976; baboon: Peplow, Breed, Jones \& Eckstein, 1973: mink, dog, armadillo, black bear: Daniel \& Krishnan, 1969; seal: Daniel, 1972; golden hamster: Noske \& Daniel, 1974; sheep: Wales, 1973; cow: Roberts \& Parker, 1974a, b; Roberts, Parker \& Symonds, 1976b; Laster, 1977; mare: Zavy, Bazer \& Sharp, 1976; various marsupials: Renfree, 1973, 1975). By and large this work serves mainly to emphasize the extraordinary biochemical diversity which appears to exist among mammalian reproductive systems. There are two species which have been studied more thoroughly and from which uterine proteins (i.e. proteins not also found in the serum of the same animal) have been isolated. These are the rabbit and the pig, from which, respectively, uteroglobin (Beier, 1968, 1974; Krishnan \& Daniel, 1968) and a phosphatase (Murray, Bazer, Wallace \& Warnick, 1972; Chen, Bazer, Cetorelli, Pollard \& Roberts, 1973; Schlosnagel, Bazer, Tsibris \& Roberts, 1974) have been purified. Uteroglobin, a glycoprotein which binds progesterone (Beato \& Baier, 1975) is a major component of rabbit uterine contents. The porcine acid phosphatase, a glycoprotein, is likewise a major component of the uterine secretions; it is secreted under the influence of exogenous progesterone, contains iron and is purple in colour. Despite much search, in no other species has anything quite like these proteins, certainly not in the amounts encountered in the rabbit and the pig, been found. A possible exception is the mare which, according to one report, produces a protein similar to that of the pig (Zavy et al., 1976).

\footnotetext{
* Died on 7 July 1978.
} 
The exploratory work of Roberts \& Parker (1974a) and Laster (1977) has demonstrated that uterine proteins are present in the cow. Initially the uterine washings used by Roberts \& Parker (1974a) provided a source of uterine protein but it rapidly became apparent that, with an average yield of $15 \mathrm{mg}$ total protein per uterine washing, of which not more than $300 \mu \mathrm{g}$ were the materials sought, this source was inadequate. Roberts \& Parker (1976) gave immunochemical evidence that protein of uterine origin may be found in allantoic and amniotic fluid. This is a far more copious source and much work has been done in an endeavour to isolate the uterine proteins from it. The fluids do have one protein in common: acid phosphatase found in fetal fluids has the same $\mathrm{pH}$ optimum and isoelectric point $(9.7)$ as the enzyme later found in bovine uterine fluid (see below). However, there are also very large amounts of protein of non-uterine origin in the fetal fluids.

Harrison, Heap, Horton \& Poyser (1972) showed that surgical separation of the uterus and the ovaries in the ewe caused the animal to become pseudopregnant and fluid to accumulate in the uterus. A preliminary electrophoretic examination of a specimen of this fluid at $\mathrm{pH} 3 \cdot 5$ showed prominent protein bands migrating as do the uterine proteins reported by Roberts \& Parker (1974a). A similar result is obtained with intact animals treated with large amounts of exogenous progesterone, and the uterine fluid of such animals was therefore investigated more extensively.

\section{Materials and Methods}

Recovery of uterine secretions. Cows of normal reproductive history were removed from the Institute herd and observed for oestrus. They were then given progesterone, $300 \mathrm{mg}$ subcutaneously in oil, daily for 2-3 months. At slaughter the uteri were exposed as rapidly as possible, clamped at the utero-tubal junctions, ligated just cranial to the internal os and excised. The uterine contents were allowed to drain from one of the uterine horns, and/or were rinsed out of this organ with $0.01 \mathrm{M}$-phosphate buffered saline, $\mathrm{pH} 7 \cdot 2$, introduced at one utero-tubal junction and recovered, after inversion and gentle massage, from the other.

Preparation of uterine proteins. The uterine contents and washings were centrifuged to remove cellular debris and the supernatant was dialysed against $0 \cdot 1 \mathrm{M}$-sodium acetate buffer, $\mathrm{pH}$ $5 \cdot 5$. To this solution $(150-175 \mathrm{ml})$ was added a slurry $(50 \mathrm{ml})$ of carboxymethyl cellulose (Whatman CM52) in the same buffer and the resulting mixture was stirred slowly at $4^{\circ} \mathrm{C}$ overnight. The carboxymethyl cellulose was recovered by filtration and washed with $0.1 \mathrm{M}$-sodium acetate buffer, $\mathrm{pH} 5 \cdot 5$, to remove unbound protein. The carboxymethyl cellulose was then resuspended in buffer and poured into a glass column $(1.5 \times 30 \mathrm{~cm}$; Pharmacia). The column was washed with 2 volumes of buffer, followed by elution of the bound proteins with $1 \mathrm{M}$-sodium

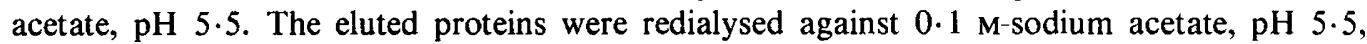
readsorbed onto carboxymethyl cellulose (Whatman CM52) and eluted using a linear ionic strength gradient between 0.1 and $1.0 \mathrm{M}$-sodium acetate, $\mathrm{pH} 5.5$. The eluate was monitored at $280 \mathrm{~nm}$ and also tested for acid phosphatase activity by the method of Schlosnagel et al. (1974). Fractions were pooled according to the elution profile to give 5 major protein fractions (Text-fig. 1).

Electrophoretic methods. Disc gel electrophoresis of the uterine protein fractions was carried out at pH 9.5 (Davis, 1964) and pH 3.5 (Reisfeld, Lewis \& Williams, 1962). Protein bands were stained with coomassie blue, $0.3 \%$ in $20 \%$ trichloracetic acid, followed by destaining in ethyl alcohol, acetic acid and water $(9: 2: 9$ by vol.). Acid phosphatase activity in gels was demonstrated as described by Andrews \& Pallavicini (1973).

Preparative isoelectric focusing was carried out using a glycerol concentration gradient (20$60 \% \mathrm{w} / \mathrm{w}$ ) between $\mathrm{pH} 7$ and 11 .

Gel filtration. Gel filtration of the uterine protein fractions was carried out on columns of Sephadex G200, G100 or G75 $\left(1.5 \times 90 \mathrm{~cm}\right.$, Pharmacia) at $4^{\circ} \mathrm{C}$; the eluant was $0.3 \mathrm{M}$-sodium 
chloride containing $0.02 \%(\mathrm{w} / \mathrm{v})$ sodium azide. The protein content of the eluate was measured by u.v. absorption at $280 \mathrm{~nm}$.

Affinity chromatography. An immunoglobulin fraction of rabbit antiserum against whole bovine serum was precipitated with $16 \%$ sodium sulphate at room temperature. The precipitated immunoglobulins were washed with $16 \%(\mathrm{w} / \mathrm{v})$ sodium sulphate, redissolved in $0.2 \mathrm{M}$-sodium citrate buffer, $\mathrm{pH} 6.5$, and dialysed against the same buffer ( 2 litres) overnight at $4^{\circ} \mathrm{C}$. This immunoglobulin solution was then coupled to Sepharose 4B activated with cyanogen bromide (Porath, Axen \& Ernbach, 1967). The coupled gel was then packed into a glass column $(1.5 \times$ $15 \mathrm{~cm}$ ) and washed with $3.0 \mathrm{M}$-sodium thiocyanate to remove unbound protein. The gel was then washed with $0.2 \mathrm{M}$-Tris- $\mathrm{HCl}, \mathrm{pH} 8 \cdot 0$, before use.

The sample was applied to the affinity column after dialysis against $0.2 \mathrm{M}-\mathrm{Tris}-\mathrm{HCl}, \mathrm{pH} 8 \cdot 0$. After washing with buffer the adsorbed proteins were eluted with $3 \mathrm{M}$-sodium thiocyanate.

Analytical ultracentrifuge experiments. Sedimentation coefficients were determined at three protein concentrations $(1,0.5$ and $0.25 \%)$ and extrapolated to zero concentration, even though the virial coefficients were small. Equilibrium runs were made in the synthetic boundary cell by the procedure of Chervenka (1970) using $0.15 \mathrm{ml}$ of a $0.5 \%(\mathrm{w} / \mathrm{v})$ protein solution with $0.4 \mathrm{ml}$ buffer. Silicone oil $(0.02$ and $0.04 \mathrm{ml})$ was placed in the solvent and solution channels respectively. Barbiturate buffer, $0.01 \mathrm{M}, \mathrm{pH} 7.0$, in $0.1 \mathrm{M}-\mathrm{NaCl}$ was used as solvent throughout. Its density and viscosity were measured at $20^{\circ} \mathrm{C}$ using a $50 \mathrm{ml}$ pyknometer and an Ostwald viscometer respectively.

Molecular weights. These were determined from plots of $\mathrm{LnC}(\mathrm{C}=$ concentration $)$ against $r^{2}$ ( $r=$ radius of rotation) from the equilibrium experiment, using Equation 2.10 of Creeth \& Pain (1967). The partial specific volume of lactoferrin was taken as $0.722 \mathrm{ml} / \mathrm{g}$ protein (Castellino, Fish \& Mann, 1970).

Amino acid analyses. These were carried out automatically (LKB 4101 apparatus) on material $(\sim 1 \mathrm{mg}$ ) which had been hydrolysed for $24 \mathrm{~h}$ in $6 \mathrm{M}-\mathrm{HCl}$ containing $0 \cdot 1 \%$ thiogly collic acid. Cysteine was determined on a separate aliquot after oxidation with performic acid (Partridge \& Davis, 1955).

Carbohydrate analyses. Hexoses were determined according to Yemm \& Willis (1954); hexosamines according to Rondle \& Morgan (1955); neuraminic acid by the method of Warren (1959). Samples were also hydrolysed in Dowex $50\left(\mathrm{H}^{+}\right.$form) as described by Gibbons (1962), reduced and acetylated (Roberts, 1974) and analysed by gas-liquid chromatography.

\section{Results}

The result of the preliminary separation is shown in Text-fig. 1. The yields of protein (mg) in each of the 5 primary fractions from the pooled material from 3 cows were respectively 1-17.9, $2-18 \cdot 6,3-14 \cdot 0,4-10 \cdot 0$ and 5-15.9. In addition, the yields of fractionated uterine secretions from 3 individual cows were also recorded (Table 1).

\section{Fractions 1 and 2}

Immunodiffusion against antiserum to whole bovine serum indicated that both these fractions contained serum protein. Gel filtration on G200 or G100 failed to effect a useful separation, although Fraction 2 did appear to have small amounts of material which behaved electrophoretically like the uterine proteins. Subsequently attempts were made to remove the serum protein on immunoadsorbent columns as described. Only very small amounts of protein were not taken out by the column and this material still reacted with the anti-bovine serum. It migrated electrophoretically as a $\gamma$-globulin but was not immunologically identical with $\operatorname{IgG}$, $\operatorname{IgM}$ or $\operatorname{Ig} \mathrm{A}$. 


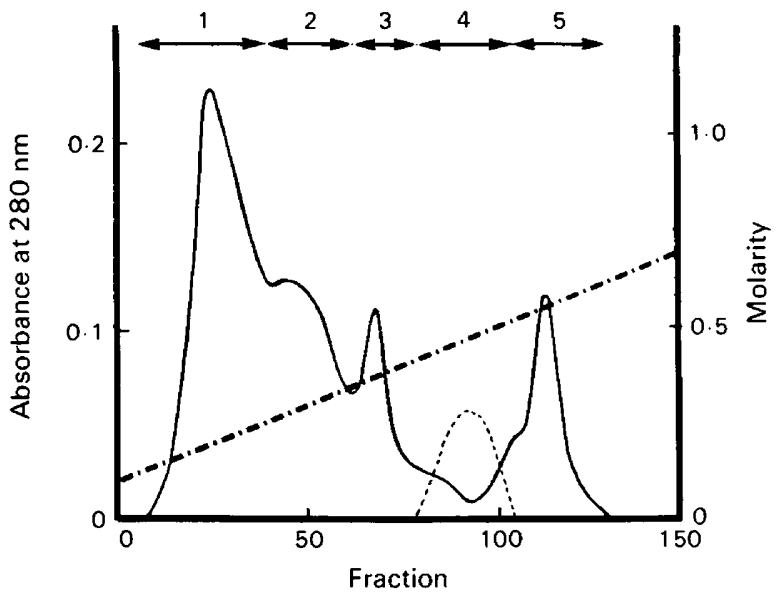

Text-fig. 1. The gradient elution on carboxymethyl cellulose of uterine proteins from progesterone-stimulated cows, showing the 5 fractions. $-\cdot-\cdot-\cdot-$ Concentration gradient; ----, acid phosphatase.

Table 1. The protein yields (mg) of each fraction obtained from the gradient elution on carboxymethyl cellulose of uterine protein obtained from cows treated with progesterone for 2 or 3 months

\begin{tabular}{cccc}
\hline Fraction & $\begin{array}{c}\text { Cow G285 } \\
\text { (2 months) }\end{array}$ & $\begin{array}{c}\text { Cow J134 } \\
\text { (2 months) }\end{array}$ & $\begin{array}{c}\text { Cow J200 } \\
\text { (3 months) }\end{array}$ \\
\hline 1 & 41.68 & 4.65 & $15 \cdot 87$ \\
2 & 11.2 & $14 \cdot 27$ & 8.79 \\
3 & $4 \cdot 16$ & 4.96 & $15 \cdot 34$ \\
4 & 4.12 & 32.08 & 2.36 \\
5 & 3.3 & 18.65 & 4.74 \\
Total protein recovered & 660 & 494 & 592 \\
\hline
\end{tabular}

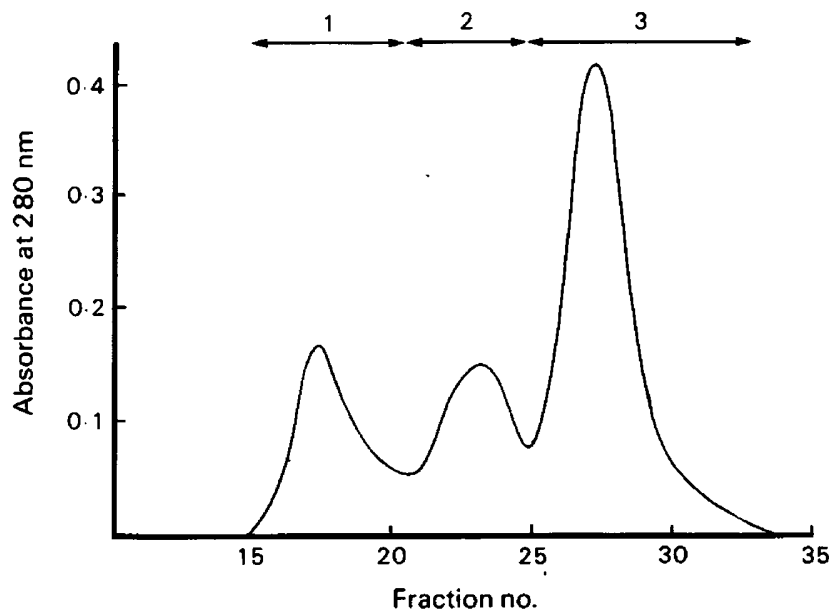

Text-fig. 2. Gel filtration (G75 Sephadex) of Fraction 3 (see Text-fig. 1) showing the 3 subfractions. 


\section{PLATE 1}

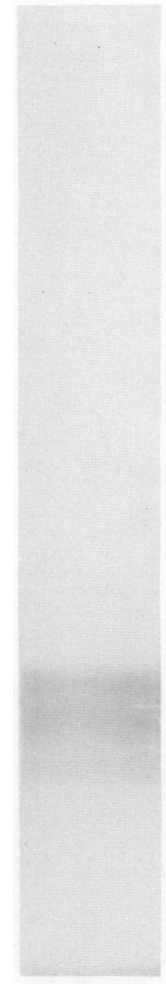

1

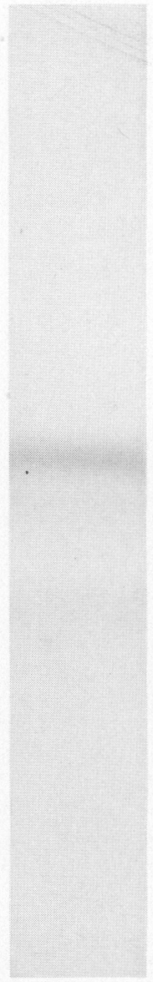

2

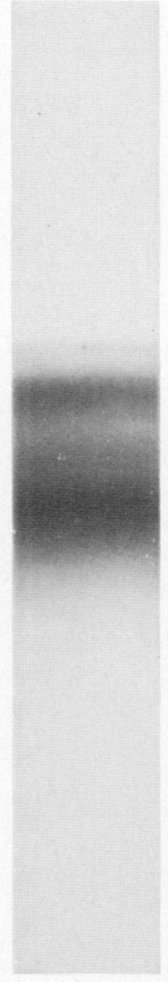

3

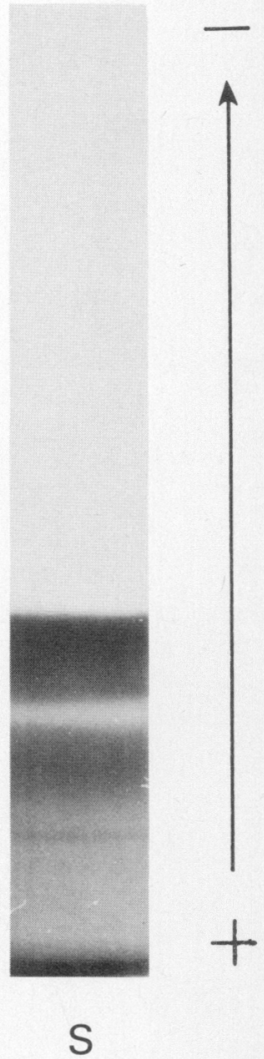

Polyacrylamide gel electrophoresis (pH 3.5) of the 3 sub-fractions obtained (see Text-fig. 2) from cow uterine secretions. $S=$ bovine serum. 


\section{Fraction 3}

This fraction contained chiefly protein which migrated electrophoretically $(\mathrm{pH} 3 \cdot 5)$ at the same rate as the uterine proteins detected by Roberts \& Parker (1974a). It was further fractionated on Sephadex G75 to yield 3 sub-fractions (Text-fig. 2). The bulk of this fraction (Subfraction 3) was of low molecular weight, and contained at least 4 electrophoretic components (Plate 1). One of these was also present as the major component of the fraction immediately preceding it in the G75 elution (Text-fig. 2). In addition 3 electrophoretic components were observed in Sub-fraction 1. None of the 7 proteins observed formed precipitin bands with antiserum to whole bovine serum.

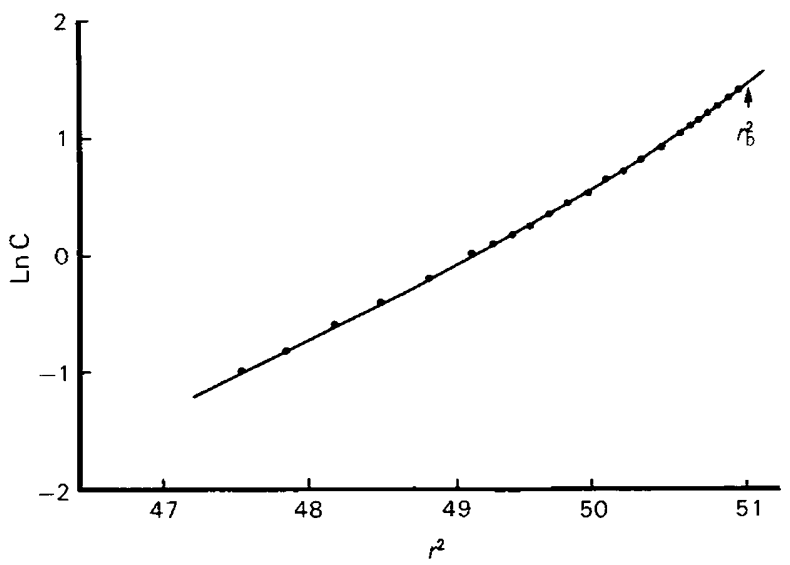

Text-fig. 3. Equilibrium sedimentation of bovine uterine lactoferrin in the analytical ultracentrifuge. $\mathrm{LnC}(\mathrm{C}=$ Concentration $)$ against $r^{2}(r=$ radius of rotation $)$ at time $t(120 \mathrm{~h} 47 \mathrm{~min})$ after reaching running speed. $r_{b}^{2}=$ cell base.

\section{Fraction 4}

This fraction contained very little protein, but almost all of the acid phosphatase activity. The major contaminant was Fraction 5, which could be removed by gel filtration on Sephadex G75 when it emerged with the excluded volume, well separated from the enzyme activity which emerged immediately afterwards. This material appeared homogeneous electrophoretically in gels at $\mathrm{pH} 9 \cdot 5$ and $3 \cdot 5$. Isoelectric focusing isolated all the activity at $\mathrm{pH} 9 \cdot 7$.

\section{Fraction 5}

This fraction consisted of a protein which gave pale brown solutions and was identical immunologically with bovine milk lactoferrin. It was a single component electrophoretically at both $\mathrm{pH} 9.5$ and 3.5 , possessing the same electrophoretic mobility as shown by bovine milk lactoferrin. It sedimented as a single component in the ultracentrifuge at $\mathrm{pH} 7 \cdot 0, S_{20 \mathrm{w}}^{\mathrm{o}}=5.62$. The molecular weight deduced from the linear portion of the $\mathrm{LnC} / r^{2}$ plot in the equilibrium sedimentation study was $8.1 \times 10^{4}$. There was some indication of aggregation, as shown by the slight curvature of the $\mathrm{LnC} / r^{2}$ plot towards the base of the cell, resulting from the conditions of pressure and concentration at the base of the cell (Text-fig. 3). The sugar and amino-acid composition of the uterine lactoferrin was compared (Tables 2 and 3) with that of a sample of milk lactoferrin analysed simultaneously. 
Table 2. Amino acid analysis of the lactoferrin (as $\mathrm{mg} / 100 \mathrm{mg}$ amino acid recovered) from the uterine secretions and milk of the cow

\begin{tabular}{lcc}
\hline Amino acid & $\begin{array}{c}\text { Bovine uterine } \\
\text { lactoferrin }\end{array}$ & $\begin{array}{c}\text { Bovine milk } \\
\text { lactoferrin }\end{array}$ \\
\hline Asparagine & 9.85 & $9.81(10.4)^{*}$ \\
Threonine & 4.87 & $5.07(4.94)$ \\
Serine & 5.18 & $5.13(5 \cdot 11)$ \\
Glutamine & 11.68 & $11.92(11.74)$ \\
Proline & 4.43 & $4.31(4.42)$ \\
Glycine & 4.39 & $4.31(4 \cdot 39)$ \\
Alanine & 6.74 & $6.82(6.91)$ \\
Cysteine (S-S) & 5.75 & $4.97(5.38)$ \\
Valine & 6.55 & $6.40(6.29)$ \\
Methionine & 0.84 & $0.74(0.878)$ \\
Isoleucine & 2.01 & $2.21(2.47)$ \\
Leucine & 9.88 & $9.88(9.88)$ \\
Tyrosine & 4.73 & $4.57(4.44)$ \\
Phenylalanine & 5.34 & $5.44(5.04)$ \\
Histidine & 1.88 & $1.81(1.91)$ \\
Lysine & 8.84 & $9.06(8.61)$ \\
Arginine & 7.08 & $7.39(7.51)$ \\
NH & 0.61 & 0.72 \\
\hline
\end{tabular}

* Data from Gordon, Groves \& Basch (1963).

Table 3. Carbohydrate analysis of the lactoferrin from the uterine secretions and milk of the cow, expressed as \% by weight of total protein

\begin{tabular}{lcccc}
\hline & $\begin{array}{c}\text { Uterine lactoferrin } \\
\text { (present study) }\end{array}$ & $\begin{array}{c}\text { Milk lactoferrin } \\
\text { (present study) }\end{array}$ & Groves (1960) & Castellino et al. (1970) \\
\hline Hexose & $4 \cdot 18^{*}$ & $5 \cdot 614$ & 4.65 & 5.6 \\
Hexosamine & $2 \cdot 37$ & $2 \cdot 15$ & 2.25 & 2.87 \\
Sialic acid & 0.19 & 0.20 & 0.3 & 0.4 \\
\hline
\end{tabular}

* Individual hexoses by g.l.c.: fucose, $0.19 \%$, galactose $0.80 \%$, glucose $0.22 \%$, mannose $3 \cdot 0 \%$.

\section{Discussion}

The criterion for recognition of bovine uterine proteins is based on their electrophoretic mobility. For example, Roberts \& Parker (1974a) observed that certain uterine proteins migrated more rapidly at $\mathrm{pH} 3.5$ than any serum component and were therefore easily distinguishable. These uterine proteins comprise not more than $2 \%$ of the total protein in the uterine secretion (Roberts \& Parker, 1974a), the remainder being identical immunologically with serum proteins and probably derived from the serum (Crutchfield \& Kulangara, 1973). A total of 9 uterine proteins have been isolated from this source.

In the present limited study, quantitative variations were observed in all fractions obtained from the gradient elution on carboxymethyl cellulose of the uterine secretions from progesterone-stimulated cows (Table 1). There did not appear to be any relationship between the period of progesterone treatment and the amount of protein recovered in each fraction. The data also suggest that there are variations in the response of individual animals to this progesterone treatment. However, 9 uterine proteins were isolated; one, obtained in a very low yield, was an 
acid phosphatase, 7 were from one fraction only, while the major protein was found to be identical to bovine milk lactoferrin. The equilibrium studies of this uterine protein revealed a molecular weight of $8.1 \times 10^{4}$, compared with published values for milk lactoferrin of $8.1 \times 10^{4}$ (Groves, 1960) and $7.7 \times 10^{4}$ (Castellino et al., 1970). Aggregation behaviour has also been reported (Castellino et al., 1970) for a sample of milk lactoferrin, and the sedimentation coefficient obtained for the uterine lactoferrin agrees well with published values for milk lactoferrin (Groves, 1960; Johansson, 1969).

Lactoferrin, deriving its name from the source from which it was originally isolated, is not peculiar to milk but has been detected in many other secretions and tissues, e.g. human endometrial secretions and tissue (Masson, Heremans \& Ferin, 1968a; Tourville, Ogra, Lippes \& Tomasi, 1970), seminal fluid, cervical mucus, urine, tears, bile and pancreatic juice (Masson, Heremans \& Dive, 1966), kidney cells (Masson, Heremans, Schonne \& Crabbe, 1968c), intestinal secretions (Lousillier, Gor, Burton \& Grabar, 1967) and bronchial secretions and saliva (Masson, Heremans, Prignot \& Wauters, 1968b). It has been shown to have bactericidal properties, a function which is based on the ability of lactoferrin to chelate ionizable iron from culture medium (Masson \& Heremans, 1967; Masson et al., 1968b; Blanc, 1967; Schade, 1967; Oram \& Reiter, 1968) and it is often inferred that it has this function in the secretions in which it is found. Lactoferrin may thus function as a bacteriostat in the bovine uterus.

In human endometrial secretions lactoferrin is secreted during the last part of the menstrual cycle under the stimulus of progesterone (Masson et al., 1968a). In the present study uterine lactoferrin was secreted by cows treated with exogenous progesterone. It thus appears that progesterone is involved in the secretion of lactoferrin in women and cows. However, in the pig, exogenous progesterone does not stimulate synthesis and secretion of lactoferrin by the endometrium, but does stimulate the secretion of the purple acid phosphatase, lysozyme, leucine amino peptidase and cathepsin $\left(B_{1}, D\right.$ and $\left.E\right)$. Lysozyme, which is absent from bovine uterine secretions, is thought to have a bactericidal function in the porcine uterus (Roberts, Bazer, Baldwin \& Pollard, 1976c).

The presence of both an acid phosphatase and metalloprotein in the pig and the cow suggests that they are both essential in some way to uterine function. In the pig, the two functions are combined in one protein, while the cow possesses two proteins. It has been postulated that the porcine acid phosphatase plays an important role in the transport of iron to the fetus as a transferrin-like molecule (Chen, Bazer, Gebhardt \& Roberts, 1975; Roberts et al., 1976c). A similar role can be postulated for lactoferrin, although we have failed to detect the presence of lactoferrin in either bovine allantoic or amniotic fluid.

We thank Mr P. Harrison and Mrs D. Knight for their technical assistance during this study.

\section{References}

Andrews, A.T. \& Pallavicini, C. (1973) Bovine milk acid phosphatase. Biochim. biophys. Acta 321, 197-209.

Beato, M. \& Baier, R. (1975) Binding of progesterone to the proteins of the uterine luminal fluid. Identification of uteroglobulin as the binding protein. Biochim. biophys. Acta 392, 346-356.

Beier, H.M. (1968) Uteroglobulin-a hormone sensitive endometrial protein involved in blastocyst development. Biochim. biophys. Acta 160, 289-291.

Beier, H.M. (1974) Oviducal and uterine fluids. $J$. Reprod. Fert. 37, 221-237.

Beier, H.M., Petry, G. \& Kühnel, W. (1970) Endometrial secretion and early mammalian development.
In Mammalian Reproduction, pp. 264-284. Eds H. Gibian \& E. J. Plotz. Springer-Verlag, Berlin.

Blanc, B. (1967) La lactotransferrine, ses relations avec les aspects physiologiques du metabolism du fer. Protides Biol. Fluids 14, 125-131.

Castellino, F.J., Fish, W.W. \& Mann, K.G. (1970) Structural studies of bovine lactoferrin. J. biol. Chem. 245, 4269-4275.

Chen, T.T., Bazer, F.W., Cetorelli, J.J., Pollard, W.E. \& Roberts, M.R. (1973). Purification and properties of a progesterone-induced basic glycoprotein from the uterine fluids of pigs. J. biol. Chem. 248, 8560 8566. 
Chen, T.T., Bazer, F.W., Gebhardt, B.M. \& Roberts, R.M. (1975) Uterine secretion in mammals: synthesis and placental transport of a purple acid phosphatase in pigs. Biol. Reprod. 13, 304-313.

Chervenka, C.H. (1970) Long column meniscus depletion sedimentation equilibrium technique for the analytical ultracentrifuge. A nalyt. Biochem. 34, 24-29.

Creeth, J.M. \& Pain, R.H. (1967) The determination of molecular weights of biological macromolecules by ultracentrifuge methods. Progr. Biophys. molec. Biol. 17, 217-287.

Crutchfield, F.L. \& Kulangara, A.C. (1973) Passage of bovine serum albumin from the mother to rabbit blastocysts. J. Embryol. exp. Morph. 30, 459-469.

Daniel, J.C. (1972) Blastokinin in the northern fur seal. Fert. Steril. 23, 78-84.

Daniel, J.C. \& Krishnan, R.S. (1969) Studies on the relationship between uterine fluid components and the diapausing state of blastocysts from blastocysts having delayed implantation. J. exp. Zool. 172, 267282.

Davis, B.J. (1964) Disc electrophoresis. Ann. N.Y. Acad. Sci. 121, 404-427.

Dupont-Mairesse, N. \& Galand, P. (1975) Estrogen action-induction of the synthesis of a specific protein in the myometrium, the stroma and the luminal epithelium of the rat uterus. Endocrinology 96, $1587-1591$.

Gibbons, R.A. (1962) The determination of glycolloyl in substances containing neuraminic acid. Analyst 87, 178-182.

Gordon, W.G., Groves, M.L. \& Basch, J.J. (1963) Bovine milk red protein: amino-acid composition and comparison with blood transferrin. Biochemistry, N.Y. 2, 178-920.

Greenstein, J.S., Murray, R.W. \& Foley, B.C. (1958) Observations on the morphogenesis and histochemistry of the bovine preattachment placenta between 16 and 33 days of gestation. Anat. Rec. 132, 321-341.

Groves, M.L. (1960) Isolation of red protein from milk. J. Am. Chem. Soc. 82, 3345-3350.

Harrison, F.A., Heap, R.B., Horton, E.W. \& Poyser, N.L. (1972) Identification of prostaglandin $F_{2 \alpha}$ in the uterine fluid from the non-pregnant sheep with an auto-transplanted ovary. J. Endocr. 53, 215-222.

Johansson, B.G. (1969) Isolation of crystalline lactoferrin from human milk. Acta chem. scand. 23, 683714.

Krishnan, R.S. \& Daniel, J.C. (1968) Composition of blastokinin from rabbit uterus. Biochem. biophys. Acta 168, 579-582.

Kunitake, G.M., Nakamura, J.M., Wells, B.G. \& Moyer, D.L. (1965) Disc electrophoretic and disc-gel Ouchterlony analysis of rat uterine fluid. Fert. Steril. 16, $120-124$.

Laster, D.B. (1977) A pregnancy-specific protein in the bovine uterus. Biol. Reprod. 16, 682-690.

Lousillier, F., Gor, R., Burton, P. \& Grabar, P. (1967) Recherches sur la localisation tissulaire et l'autoantigenicité de la lactotransferrine. Protides Biol. Fluids 14, 133-142.

Masson, P.L. \& Heremans, J.F. (1967) Studies on lactoferrin, the iron binding protein of secretion. Protides Biol. Fluids 14, 115-124.
Masson, P.L., Heremans, J.F. \& Dive, C. (1966) An iron binding protein common to many external secre tions. Clin. chim. Acta 14, 735-739.

Masson, P.L., Heremans, J.F. \& Ferin, J. (1968a) Presence of an iron binding protein (lactoferrin) in the genital tract of the human female. I. Its immunohistochemical localisation in the endometrium. Fert. Steril. 19, 679-689.

Masson, P.L., Heremans, J.F., Prignot, J.J. \& Wauters, G. (1968b) Immuno-histochemical localisation and bacteriostatic properties of an iron-binding protein from bronchial mucus. Thorax 21, 538-544.

Masson, P.L., Heremans, J.F., Schonne, E. \& Crabbe, P.E. (1968c) New data on lactoferrin the iron binding protein of secretions. Protides Biol. Fluids 16, 633-638.

Milton, A.A., Berry, R.O. \& Butler, D.D. (1951) The interval between the time of ovulation and attachment of the bovine embryo. J. A nim. Sci. 10, 9931005.

Murray, F.A., Bazer, F.W., Wallace, H.D. \& Warnick, A.C. (1972) Quantitative and qualitative variation in the secretion of protein by the porcine uterus during the estrous cycle. Biol. Reprod. 7, 314320.

Noske, I.G. \& Daniel, J.C. (1974) Changes in the uterine and oviducal fluid proteins during early pregnancy in the golden hamster. J. Reprod. Fert. 38, 173-176.

Oram, J.D. \& Reiter, B. (1968) Inhibition of bacteria by lactoferrin and other iron chelating agents. Biochim. biophys. Acta 170, 351-365.

Partridge, S.M. \& Davis, H.F. (1955) Composition of the soluble proteins from elastin. Biochem.J. 61, 2130.

Peplow, V., Breed, W.G., Jones, C.M.J. \& Eckstein, P. (1973) Studies on the uterine flushings in the baboon. Am. J. Obstet. Gynec. 110, 771-779.

Perrine, J.W. (1967) Formation and composition of rat uterine fluid. Diss. Abstr. 27, 2854-2855.

Porath, J., Axen, R. \& Ernbach, S. (1967) Chemical coupling of proteins to agarose. Nature, Lond. 215 , 1491-1492.

Reisfeld, R.A., Lewis, U.J. \& Williams, D.E. (1962) Disc electrophoresis of basic proteins and peptides on polyacrylamide gels. Nature, Lond. 195, 281-283.

Renfree, M.B. (1973) Proteins in the uterine secretions of the marsupial Macropus eugenii. Devl Biol. 32, 4149.

Renfree, M.B. (1975) Uterine proteins in the marsupial Didelphis marsupialis virginiana during gestation. $J$. Reprod. Fert. 42, 163-166.

Roberts, G.P. (1974) Isolation and characterisation of glycoproteins from sputum. Eur. J. Biochem. 50, 265-280.

Roberts, G.P. \& Parker, J.M. (1974a) Macromolecular components of the luminal fluid from the bovine uterus. J. Reprod. Fert. 40, 291-304.

Roberts, G.P. \& Parker, J.M. (1974b) An investigation of enzymes and hormone-binding proteins in the luminal fluid of the bovine uterus. J. Reprod. Fert. 40, 305-313.

Roberts, G.P. \& Parker, J.M. (1976) Fractionation and comparison of proteins from bovine uterine fluid and bovine allantoic fluid. Biochim. biophys. Acta 446 , $69-76$. 
Roberts, G.P., Parker, J.M. \& Henderson, S.R. (1976a) Proteins in human uterine fluid. J. Reprod. Fert. 48, 153-157.

Roberts, G.P., Parker, J.M. \& Symonds, H.W. (1976b) Macromolecular components of the genital tract fluids from the sheep. J. Reprod. Fert. 48, 99-107.

Roberts, R.M., Bazer, F.W. Baldwin, N. \& Pollard, W.E. (1976c) Progesterone induction of lysozyme and peptidase activities in the porcine uterus. Archs. Biochem. Biophys. 177, 499-507.

Rondle, C.J.M. \& Morgan, W.T.J. (1955) The determination of glucosamine and galactosamine. Biochem. J. 61, 586-589.

Rowson, L.E.A. \& Moor, R.M. (1966) Embryo transfer in the sheep: the significance of synchronising oestrus in the donor and recipient animal. J. Reprod. Fert. 11, 207-212.

Rowson, L.E.A., Lawson, R.A.S., Moor, R.M. \& Baker, A.A. (1972) Egg transfer in the cow; synchronisation requirements. J. Reprod. Fert. 28, 427-431.

Schade, A.L. (1967) Non-heme metalloproteins: their distribution, biological function and chemical characterisation. Protides Biol. Fluids 14, 13-23.

Schlosnagel, D.C., Bazer, F.W., Tsibris, J.C.M. \&
Roberts, R.M. (1974) An iron containing phosphatase induced by progesterone in the uterine fluid of pig. J. biol. Chem. 249, 7574-7579.

Tourville, D.R., Ogra, S.S., Lippes, J. \& Tomasi, T.B. (1970) The human female reproductive tract: immunohistological localisation of $\gamma \mathrm{A}, \gamma \mathrm{G}, \gamma \mathrm{M}$ secretory "piece" and lactoferrin. Am. J. Obstet. Gynecol. 108, 1102-1108.

Umpathysivam, K. \& Breed, W.G. (1976) Protein composition of uterine flushings of rats in different endocrinological states. Theriogenology 6, 628 .

Wales, R.G. (1973) The uterus of the ewe. Chemical analysis of uterine fluid collected by cannulation. Aust. J. biol. Sci. 26, 947-959.

Warren, L. (1959) The thiobarbituric acid assay of sialic acids. J. biol. Chem. 234, 1971-1975.

Wolf, D.P. \& Mastroianni, L. (1975) Composition of human uterine fluid. Fert. Steril. 25, 240-247.

Yemm, E.W. \& Willis, A.J. (1954) The estimation of carbohydrates in plant extracts by anthrone. Biochem. J. 57, 508-514.

Zavy, M.T., Bazer, F.W. \& Sharp, D.C. (1976) Uterine luminal protein in the cycling mare. J. Anim. Sci. 43, 312, Abstr.

Received 1 August 1978 